\title{
Falafel: A Meal with Full Nutrition
}

\section{Mohammed Ismail, Erdogan Kucukoner ${ }^{*}$}

Department of Food Engineering, Engineering Faculty, Suleyman Demirel University, Isparta, Turkey

Email: *erdogankucukoner@sdu.edu.tr,mohamed_ani3@yahoo.com

How to cite this paper: Ismail, $M$. and Kucukoner, E. (2017) Falafel: A Meal with Full Nutrition. Food and Nutrition Sciences, 8, 1022-1027.

https://doi.org/10.4236/fns.2017.811074

Received: October 10, 2017

Accepted: November 24, 2017

Published: November 27, 2017

Copyright (C) 2017 by authors and Scientific Research Publishing Inc. This work is licensed under the Creative Commons Attribution International License (CC BY 4.0).

http://creativecommons.org/licenses/by/4.0/

\begin{abstract}
There are a lot of fried food recipes that contain vegetables as a main ingredient. One of the most famous fried vegetables in the Middle East is Falafel. Falafel is a traditional Egyptian and Middle Eastern food with deferent names from country to another, for examples it is called Falafel in Iraq and Levant, and it is called Ta'amiya in Egypt. Falafel is a vegetarian recipe which reflects its nutritious value. In this article, we are going to refer to the definition of Falafel and its origin to show that Falafel is a global dish. In addition, the ingredients of Falafel are going to be mentioned. Finally, the benefits of Falafel are going to be explained to show how Falafel is considered as a nutritious meal. This study has discovered that Falafel is one of the healthy vegetarian meals due to its ingredients which are full of vitamins and also considered as a very rich source of dietary fiber.
\end{abstract}

\section{Keywords}

Falafel, Ta’amiya, Nutrition, Vegetarian, Deep-Fried Ball

\section{What Is Falafel and What Is Made of?}

Falafel is a deep-fried ball or patty made from dried ground chickpeas, fava beans, (Figure 1, Figure 2) or both and soaked for a period of time in water and then grind and kneaded and add the spices, then fried in hot oil in the form of tablets [1]. It is mainly made of beans or chickpeas soaked for a while in water before being grinded and kneaded with onion, garlic, spices, and then fried in oil in the form of tablets [2] [3], some add parsley, paprika and sesame seeds to it. In soaking, baking soda is often used to make it more airy [4].

In Syria, they use chickpeas to male Falafel, and the eat it by wrapped in a flatbread with pickled vegetables and tahini-based sauces (Figure 3). In Jordan, they use mix of chickpeas and fava beans in preparing this meal and eat it by the same way in Syria [5]. 


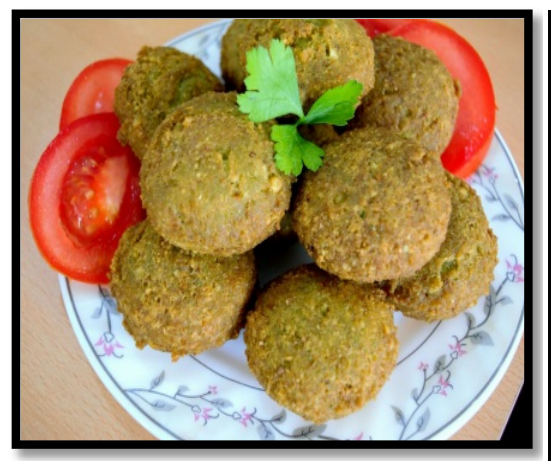

(a)

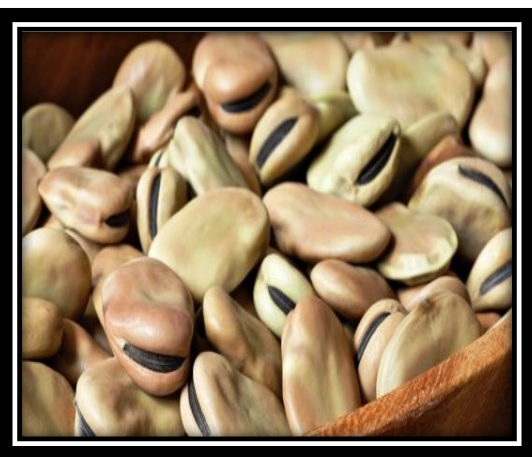

(b)

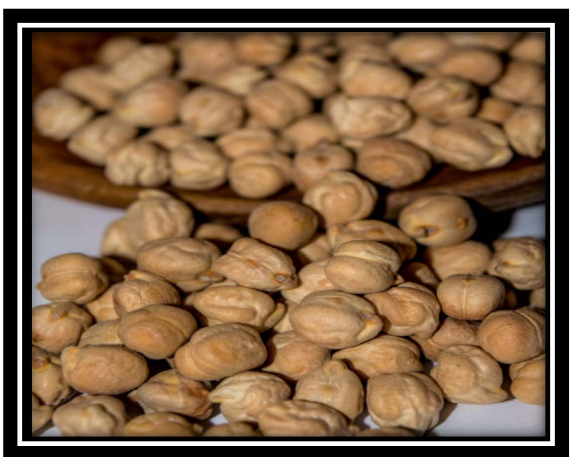

(c)

Figure 1. (a) Falafel balls with its main ingredients (b) Fava beans (vicia faba) and (c) Chickpeas (Cicer arietinum).

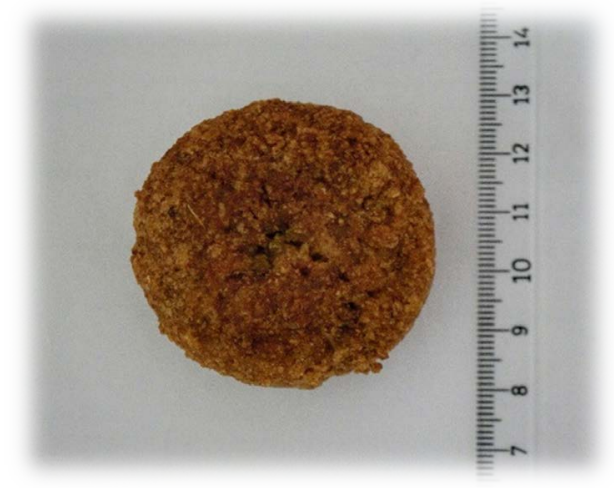

Figure 2. Falafel pie.

Falafel is a Jordanian popular food composed of chickpeas, parsley, onion, garlic, salt, and sodium bicarbonate and served after frying in palm or soybean oils for $3 \mathrm{~min}$ [6] [7].

In Egypt, they use Fava beans and they called it Ta'amiya and they used their traditional bread for making falafel sandwich (Figure 4) [5] [8] [9].

In Iraq, they use chickpeas, and they use the traditional bread and a special Indian spice in the sandwich which gives the falafel a special flavor which makes it differ from other Arabic countries (Figure 5).

To make the special shape of Falafel, there is a special mold, and sometimes before frying sesames is used to cover the tablet of the Falafel on the upper surface like decorate and to give it a flavor (Figure 6, Figure 7).

\section{But Where Did It Come from?}

Despite the disagreement over the origin, but it is a popular, cheap and nutritious meal at the same time which has gained an international reputation, namely, Falafel or Ta'amiya as the Egyptians like to call it. And here it cannot be without mentioning the conflict about the historical origin and the first who manufacture it and the creativity in making it. The people of the world have agreed to eat falafel and enjoy its taste, but they are still different about its origin. 


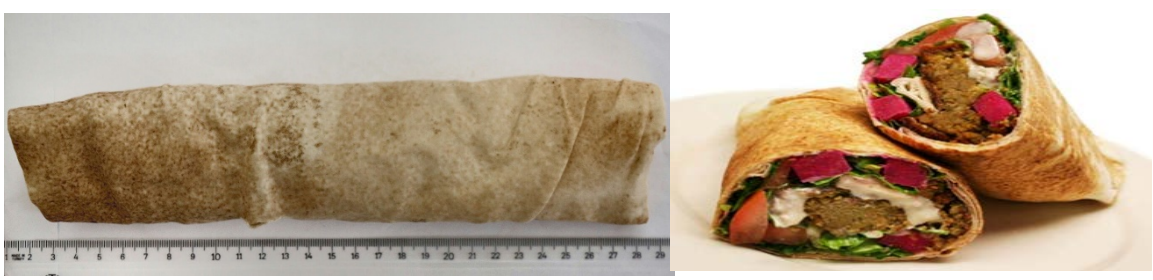

Figure 3. Syrian Falafel Sandwich.

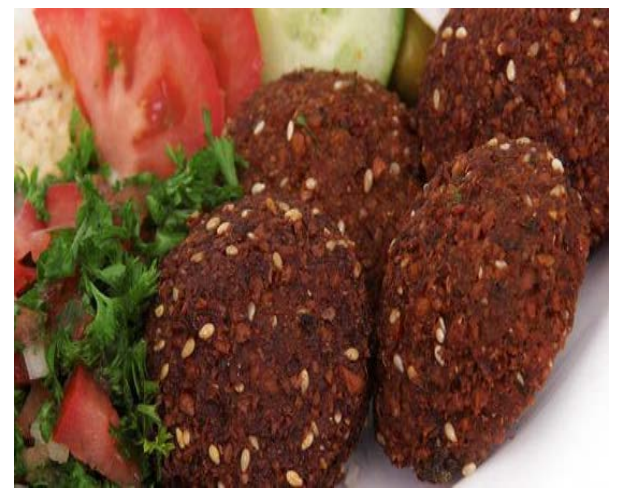

Figure 4. Egyptian Falafel Ta'amiya.

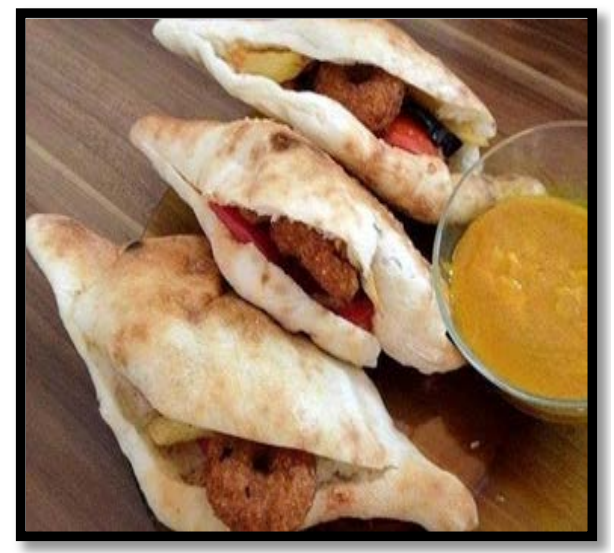

Figure 5. Iraqi Falafel Sandwich.

It is said that Egyptians are the first people who knew bean plant and have it as a human food, and they confirm that Falafel is an Egyptian invention one hundred percent. They also approve that by referring to the origin of the name, the word Falafel is an Egyptian word inherently derived from the word "Pepper", which explains the chili taste which is one of the characteristic of the Egyptian falafel. While the other name of the Falafel which is Ta'amiya is also openly endorsed it by a large number of Egyptians and say that it comes from the Egyptian dialect which derived from the Arabic word "ta'am" which means "taste". The Egyptians Chefs also confirm that the Pharaohs were the first to know Falafel or Ta'amiya, and they had stuffed it with many fillings to add more nutritional value to it, for example it was stuffed with liver or meat and sometimes eggs, to the extent that it became as a companion to the ancient Egyptian in his travels for its ability to fill the hunger [8]. 


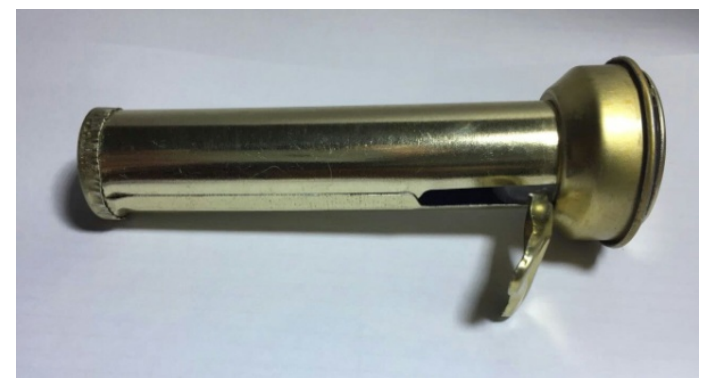

Figure 6. This is the traditional mold.

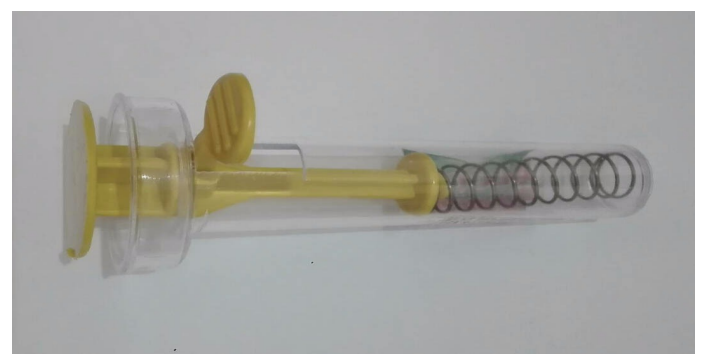

Figure 7. This is the modern which shows its mechanizim.

On the other hand, others believe that Falafel was first known to the Syrians in the middle ages, and it has spreaded in the country of Jordan, Palestine, Lebanon and Egypt through trade trips between those countries, subsequently to move to all other countries through travelers who liked its Syrian taste. Others believe that falafel is known, the first time, in Palestine, and have evolved over time to acquire its current form, and this view is supported by a number of Palestinians scholars.

It's uncontroversial, that the Falafel is a global dish and it is common in Egypt, Palestine, Jordan, Lebanon and Syria. The method of manufacture varies between Egypt and Levant [3].

\section{Nutritional Facts of Falafal}

Recently many of the European scientific researchers have shown the benefits of Falafel on the health because it is rich in olive oil, vegetables, legumes, either beans or chickpeas or nuts and high-fiber and all of them maintain health and ideal weight and prevent obesity, diabetes and hypertension blood, thus reduce heart disease and arteries. In addition, it does not harm the body as fast food which is rich in saturated fat, such as hamburger. Therefore, Falafel is lighter in damage from all those fast food. The head of the Medical Center in America pointed out that Falafel Sandwich components made of natural materials and high nutritional specifications. Its foundation made of chick peas or beans with green leafy vegetables and olive oil, onion, garlic, coriander and spices which make the Falafel suitable food and healthy fast for those looking for speed [10].

According to the above Table 1, Falafel contains around 325 calories for 100 grams. It's made out of 35 percent water, 30 percent carbohydrates, 15 percent 
Table 1. Mineral contents of Falafel (mg/100 g edible portion) (adopted from [6] Dashti B. et al. 2004).

\begin{tabular}{cccccccc}
\hline $\mathrm{Na}$ & $\mathrm{K}$ & $\mathrm{Ca}$ & $\mathrm{P}$ & $\mathrm{Mg}$ & $\mathrm{Fe}$ & $\mathrm{Cu}$ & $\mathrm{Zn}$ \\
\hline $496 \pm 21$ & $808 \pm 49$ & $35.6 \pm 3$ & $163 \pm 7$ & $39.9 \pm 2$ & $3.36 \pm 0.3$ & $0.50 \pm 0$ & $1.68 \pm 0.3$ \\
$\mathrm{Mn}$ & $\mathrm{B}$ & $\mathrm{Cr}$ & $\mathrm{Al}$ & $\mathrm{Mo}$ & $\mathrm{Se}$ & $\mathrm{I}$ & \\
$0.50 \pm 0$ & $0.10 \pm 0$ & $0.03 \pm 0.02$ & $1.51 \pm 0$ & $0.29 \pm 0.1$ & $1.50 \pm 0$ & $0.17 \pm 0$ & \\
\hline
\end{tabular}

protein and some 20 percent of the rest-which may include some fat and also vitamins and minerals, such as potassium and magnesium. When deep fried, the falafel contains relatively little fat, and when eaten with salad it is both satiating and healthy [4].

In more details, the piece of Falafel from chickpeas or beans or both contains high-quality protein which is an important nutrient for the body and bones, that provide the body with anti-high oxidative due to the coriander and green leafy vegetables and garlic contain Allicin acid materials which are useful to the body and which strengthen the immune system and protect it from the dangers of heart disease. In addition to many minerals such as phosphorus, potassium, calcium and magnesium, zinc, iron, and it is also a very rich source of dietary fiber. In addition to the small amount of fat, sugar, it also contains Vitamin B and Vitamin K, Vitamin A and beta-carotene, as well as the first component that the bean contains, is the sleep hormone that helps supply the body with energy and recovery and reduce constipation due to the high fiber as it protects from colon cancer and enhances bowel movement and finally helps to expel toxins and waste from the body [10] [11] [12].

\section{Conclusion}

As a result of what is mentioned above, Falafel is widely distributed in the world because of the immigrants from the Middle East as well as for being tasty and healthy food and this made Falafel a popular snack in most of the countries in the world. More scientific research is needed about Falafel in order to reveal the effects on health, nutritional value and structure of it.

\section{References}

[1] Gonzalez, M.H. and Katz D.L. (2002) Way to Eat: A Six-Step Path to Lifelong Weight Control. Sourcebooks, Inc., Naperville, Illinois.

[2] Joanne, L. (1996) New Ways with Falafel. Vegetarian Times, Issue 230, 36.

[3] Al-Hofi, N. (2007) Falafel: Different Ingredients for a Meal with a Complete Nutritional Value. Middle East Magazine http://archive.aawsat.com/details.asp?issueno=10261\&article

[4] Galili, S. (2007) Falafel Fact Sheet. Ynet News, Retrieved February 6, 2011.

[5] Anonymous (2017) Falafel. Middle Eastern food. Wikipedia https://en.wikipedia.org/wiki/Falafel

[6] Dashti, B., Al-Awadi, F., Al Kandari, R., Ali, A. and Al-Otaibi, J. (2004) Macro- and Microelements Contents of 32 Kuwaiti Composite Dishes. Food Chemistry, 85, 
331-337. https://doi.org/10.1016/j.foodchem.2003.05.001

[7] Al-Degs, Y.S., Al-Ghouti, M. and Salem, N. (2011) Determination of Frying Quality of Vegetable Oils used for Preparing Falafel Using Infrared Spectroscopy and Multivariate Calibration. Food Analytical Methods, 4, 540-549.

https://doi.org/10.1007/s12161-011-9201-9

[8] Raviv, Y. (2003) Falafel: A National Icon. Gastronomica: The Journal of Critical Food Studies, 3, 20-25. https://doi.org/10.1525/gfc.2003.3.3.20

[9] Malouf, G. and Malouf, L. (2008) Artichoke to Za'atar: Modern Middle Eastern Food. University of California Press, Oakland, California, USA.

[10] Ayat, T. (2016) Benefits and Harms of Falafel. Almrsalcom http://www.almrsal.com/post/300940

[11] Jukanti, A.K. (2012) Nutritional Quality and Health Benefits of Chickpea (Cicer Arietinum L.): A Review. British Journal of Nutrition, 108, 11-26. https://doi.org/10.1017/S0007114512000797

[12] Rachwa-Rosiak, D. (2015) Chickpeas-Composition, Nutritional Value, Health Benefits, Application to Bread and Snacks: A Review. Critical Reviews in Food Science and Nutrition, 55, 1137-1145.

https://doi.org/10.1080/10408398.2012.687418 